\title{
MUTU ORGANOLEPTIK COOKIES DENGAN PENAMBAHAN TEPUNG BEKATUL DAN IKAN KEMBUNG
}

\author{
Nadimin $^{1}$, Sirajuddin ${ }^{1}$, Nuraliah Fitriani ${ }^{2}$ \\ ${ }^{1}$ Jurusan Gizi, Politeknik Kesehatan Kemenkes, Makassar \\ ${ }^{2}$ Alumni Sarjana Terapan Gizi, Politeknik Kesehatan Kemenkes, Makassar
}

Korespondensi : nadimingizi66@gmail.com/08124241003

\begin{abstract}
Additional food should use inexpensive and reasonably-available local foodstuffs such as bran and mackerel. Bekatul has a nutrient producing nutrients that are high enough but not yet utilized optimally. While bloating is an essential source of protein and fatty acids that are essential for growth. This research aims to determine the quality of organoleptik Cookies add starch and pufferfish.

Research using the design of group comparison design, comparing the quality of the original including Cookies (F1) and cookies replenishment of rice bran and pufferfish (F2). Organoleptik quality is assessed sensory based on the favorite level of panelist against the color, texture, aroma and flavor aspects. The favorite level is made in six levels ranging from dislikes to very very fond (score 1-6). Data analysis using the Mann Whitney $U$ test.

Panelis who liked the color of cookies F1 $62.9 \%$ and cookies F2 $57.1 \%$, liked the texture of cookies F1 65.7\% and cookies F2 65.7\%. Panelist who likes to aroma cookies F1 85.7\% and cookies F2 54.3\% and likes to taste cookies F1 82.9\% and cookies $F 262.9 \%$. There is no quality difference organoleptik between the F1 cookies and cookies $F 2$ of the color aspects $(P=0,511)$ and texture $(P=0,787)$. There is a significant difference in the quality of organoleptik between the F1 cookies and cookies $F 2$ from the aroma aspect $(P=0,003)$ and flavor $(P=$ 0,013). $U$.

Addition of rice bran and mackerel does not affect the quality of organoleptik from the color and tektur aspects, but can reduce the quality of organoleptik from the aroma and color aspects of cookies. It is necessary to reduce the concentration of bloated fish flour and add other ingredients that can mask the aroma and flavor of fish.
\end{abstract}

Keywords: organoleptik, cookies, Bran, pufferfish

\section{PENDAHULUAN}

Jumlah balita yang mengalami kekurangan gizi di Indonesia masih tinggi. Hasil Riskesdas tahun 2018 menunjukkan prevalensi gizi kurang sebanyak 13,8 persen dan gizi buruk - kurang sebesar 17,7 persen. Diantara 34 Provinsi, Sulawesi Selatan menempati urutan ke 10 jumlah balita gizi kurang tertinggi yaitu
15,6 persen (Kemenkes, 2018). Data Pemantauan Status Gizi (PSG) 2017 menunjukkan prevalensi buruk pada balita usia $0-59$ bulan mencapai 4,9\% (Dinkes, 2017).

Kekurangan gizi pada anak balita disebabkan dua faktor utama yaitu kurangnya asupan zat gizi dan gangguan kesehatan. Salah satu program untuk 
memenuhi kebutuhan gizi anak adalah dengan memberikan makanan tambahan. Namun, upaya pemberian makanan tambahan juga belum dapat menuntaskan kasus gizi kurang dan gizi buruk. Salah satu bentuk perhatian untuk balita gizi kurang adalah kreativitas untuk memenuhi modifikasi bahan pangan. Produk makanan yang bisa dimodifikasi adalah cookies (Selviyanti, 2018).

Pembuatan cookies biasa menggunakan terigu. Secara umum terigu memiliki harga yang relatife mahal sehingga pembuatannya perlu dimodifikasi dengan memanfaatkan bahan pangan lokal lain, seperti bekatul. Bekatul merupakan hasil samping pengolahan padi atau gabah yang terbentuk dari lapisan luar beras pecah kulit dalam penyosohan untuk menghasilkan beras putih atau beras kepala. Penggilingan padi menghasilkan bekatul sekitar $8-12 \%$. Berdasarkan sumbernya, protein yang terdapat dalam bekatul dapat dimanfaatkan untuk dibuat suatu produk yang dimungkinkan dapat mengatasi masalah kurang gizi (Wulandari, 2010). Menurut SNI, standar protein untuk snack pada anak balita yaitu 5 gram.

Hasil penelitian yang dilakukan Dodik (2017) menyebutkan bahwa kandungan protein bekatul adalah 16,27\% pada bekatul varietas IR 64, karbohidrat tertinggi $58,69 \%$ pada bekatul varietas Situbagendit, kandungan lemak tertinggi $5,59 \%$ pada bekatul varietas Situbagendit, dan kandungan mineral $15,02 \%$ tertinggi pada bekatul varietas Situbagendit. Penggunaan bekatul pada pembuatan biskuit dengan bahan dasar tepung terigu sebanyak 100 gr dengan variasi penambahan bekatul menunjukkan bahwa semakin tinggi penambahan bekatul maka semakin tinggi pula kadar protein dari biskuit tersebut. Namun sebagian masyarakat Indonesia menganggap kalau bekatul hanya bisa dijadikan pakan ternak (Wulandari, 2010).
Di sisi lain, Indonesia adalah negara penghasil ikan yang banyak mengandung zat gizi terutama sebagai sumber protein dan penghasil asam amino untuk pertumbuhan anak. Salah satu sumber protein hewani yang terkenal dimasyarakat adalah ikan kembung. Sulawesi Selatan termasuk daerah sentral produksi ikan laut. Salah satu diantaranya adalah ikan kembung, yang dalam Bahasa Makassar disebut banyar atau Banyara. Selain produksi yang melimpah, ikan kembung juga tergolong murah dan kaya akan zat gizi. Ikan kembung (Rastrelliger kanagurta $L$ ) adalah ikan air laut yang banyak didapatkan pada musim puncak (Maret - Juni). Omega 3 dan omega 6 banyak terkandung pada ikan kembung yang baik bagi pencegahan penyakit dan kecerdasan otak.

Hasil penelitian Nalendrya (2016) mengatakan bahwa dalam $100 \mathrm{~g}$ sosis ikan kembung mengandung kadar air 44,48\%, abu $2,64 \%$, lemak $5,4 \%$, protein $9,4 \%$, karbohidrat $37,88 \%$ dan omega $30,18 \mathrm{~g}$. Sosis ikan kembung mampu menyumbangkan omega 3 mencapai $20 \%$ Angka Kecukupan Gizi (AKG) anak usia 7 sampai 9 tahun. Tepung ikan mengandung protein $31 \%$, tepung daging dan tulang ikan mengandung protein $35,15 \%$, tepung kedelai mengandung protein $30,55 \%$, dan tepung jagung mengandung protein 10,33\% (Pravita, 2014).

Pengolahan tepung bekatul dan tepung ikan kembung dalam bentuk cookies dapat dijadikan salah satu alternatif dalam upaya mengatasi malnutrisi dengan mempertimbangkan dari segi zat gizi, manfaatnya bagi kesehatan dan daya terima. Pada umumnya cookies memiliki kandungan gizi karbohidrat yang tinggi sedangkan protein tergolong rendah. Kandungan gizi protein cookies dapat ditingkatkan dengan subtitusi pangan sumber protein yaitu bekatul dan ikan kembung. Tepung ikan memiliki kelebihan yaitu daya simpan yang cukup lama pada 
suhu kamar tanpa banyak mengalami perubahan, mudah digunakan untuk bahan baku pembuatan produk makanan dan merupakan sumber protein yang baik (Kurnia, 2008).

Penelitian ini bertujuan untuk mengetahui mutu organoleptik cookies dengan subtitusi tepung bekatul dan tepung ikan kembung. Mutu organoleptik dinilai berdasarkan aspek warna, tekstur, aroma dan rasa.

\section{METODE}

\section{Jenis dan Desain Penelitian}

Penelitan ini merupakan penelitian Pra Eksperimental yang dilakukan untuk mutu organoleptik cookies dengan penambahan tepung bekatul dan tepung ikan kembung. Desain penelitan menggunakan Static Group Comparison desaign.

\section{Pembuatan Tepung Ikan Kembung dan} Tepung Bekatul

Persiapan utama dalam pembuatan cookies "Tepung Bekatul dan Tepung Ikan Kembung (TBTI)" dalam penelitian ini adalah pembuatan tepung ikan kembung diawali dengan sortasi ikan. Ikan yang telah dicuci dibersihkan sirip dan dibuang isi perutnya lalu ikan yang telah bersih ditimbang. Berat mentah ikan sebelum dibersihkan sebanyak $1.8 \mathrm{Kg}$ setelah dibersihkan sebanyak $1,37 \mathrm{Kg}$. Ikan direndam dalam perasan air jeruk nipis selama 15 menit kemudian dikukus dengan serai 30 menit. Daging ikan kembung yang telah dikukus selanjutnya diangkat dan ditiriskan kemudian disuir-suir menjadi ukuran kecil serta dipisahkan antara daging ikan, tulang ikan serta kulit ikan beratnya sebanyak 711 gram. Daging ikan yang telah dikukus kemudian dikeringkan menggunakan oven dengan suhu $55^{\circ} \mathrm{C}$ selama 20 jam. Setelah daging ikan kering dihaluskan menggunakan blender dan diayak menggunakan ayakan 60 mesh. Selanjutnya tepung ditimbang, berat tepung setelah diayak yaitu sebanyak 210 gram. Tepung ikan kembung dapat digunakan pada penelitian pembuatan biskuit Bekatul diperoleh dari pabrik beras terbesar di Kabupaten Gowa yang memang memisahkan antara dedak halus, bekatul dan dedak kasar. Bekatul yang diperoleh beratnya sebanyak $1 \mathrm{Kg}$. Kemudian diayak menggunakan saringan biasa lalu disangrai selama 3-7 menit. Pada saat penyangraian bekatul ditambahkan daun pandan. Daun diayak kembali menggunakan saringan 60 mesh. Tepung bekatul siap digunakan.

\section{Pembuatan Cookies}

Proses pembuatan cookies dengan subitusi tepung bekatul dan tepung ikan kembung ditambahkan setelah semua bahan tercampur. cookies dipanggang dalam oven pada suhu $\pm 155^{\circ} \mathrm{C}$ selama 15 menit. cookies subtitusi tepung bekatul dan tepung ikan kembung dengan perbandingan 65 gr tepung terigu ditambahkan 25 gram (25\%) tepung bekatul serta 10 gram tepung ikan kembung (10\%). Selain itu dibuat juga cookies yang $100 \%$ mengandung tepung terigu tanpa ada penambahan tepung bekatul dan tepung ikan kembung (0\%). Masing-masing adonan meiliki berat yang sama yaitu 17 gram per porsinya.

\section{Cara Pengumpulan Data}

Mutu organoleptik yang diperoleh melalui uji organoleptik melalui pengisian formulir oleh panelis. Formulir berisi 4 aspek sensoris yaitu warna, aroma, rasa dan tekstur. Penilaian mutu organoleptik ini menggunakan skala hedonic yang terdiri atas 6 (tingkatan) yaitu: amat sangat suka (skor $=6$ ), sangat suka (skor $=5$ ), suka ( (kor $=4$ ), agak suka ( skor $=3$ ), tidak suka (skor $=2$ ), amat tidak suka (skor $=1$ ).

Proses penilaian mutu organoleptik dilakukan dengan tahapan sebagai berikut:

a. Sebelum penilaian dilakukan produk yang akan dinilai diletakkan dalam kemasan 
b. Formulir penilaian dan produk yang akan dinilai diletakkan dimeja panelis. Air mineral juga diletakkan dimasing-masing meja penilaian panelis

c. Panelis dipersilahkan duduk pada kursi yang telah dipersiapkan

d. Panelis diberikan waktu \pm 10 menit untuk menilai produk.

\section{Cara Pengolahan dan Analisis Data Data}

Pengolahan dilakukan dengan menggunakan program aplikasi pengolah data dan menggunakan program Microsoft. Excel. Sebelum data di input dalam program aplikasi pengolah data, data-data

Tabel 1.

Mutu Organoleptik Cookies Penambahan Tepung Bekatul dan Ikan Kembung

\begin{tabular}{lccccccc}
\hline \multirow{2}{*}{$\begin{array}{l}\text { Aspek } \\
\text { organoleptik }\end{array}$} & Formula & \multicolumn{4}{c}{ Tingkat kesukaan } & \multicolumn{2}{c}{ Total } \\
\cline { 3 - 7 } & & Suka & \multicolumn{3}{c}{ Kurang } & n & $\%$ \\
\cline { 2 - 7 } & F1 & 22 & 62.9 & 13 & 37.1 & 35 & 100 \\
& W2 & 20 & 57.1 & 15 & 42,9 & 35 & 100 \\
\hline Tekstur & F1 & 23 & 65.7 & 12 & 34.3 & 35 & 100 \\
& F2 & 23 & 65.7 & 12 & 34.3 & 35 & 100 \\
\hline Aroma & F1 & 30 & 85.7 & 5 & 14.3 & 35 & 100 \\
& F2 & 19 & 54.3 & 16 & 45.7 & 35 & 100 \\
\hline Rasa & F1 & 29 & 82.9 & 6 & 29 & 35 & 100 \\
& F2 & 22 & 62.9 & 13 & 37.1 & 35 & 100 \\
\hline
\end{tabular}

F1: Cookies tanpa subtitusi tepung bekatul dan tepung ikan kembung

F2: Cookies subtitusi tepung bekatul 25\% dan tepung ikan kembung $10 \%$

Berdasarkan penilaian panelis maka Cookies F1 lebih banyak disukai oleh panelis dibadingkan Cookies F2, terutama dari aspek rasa dan aroma. Panelis yang menyatakan suka pada rasa Cookies F1 sebanyak $83 \%$ sedangkan Cookies F2 tersebut dilakukan proses editing untuk mencegah penginputan data yang salah.

Data yang telah diperoleh selanjutnya diolah dengan deskriptif dan analitik. Analisis dekskriptif menggunakan nilai rata-rata (mean) dan presentase $(\%)$. Untuk menguji hipotesis dilakukan dengan menggunakan uji statistik, yaitu uji $T d u a$ sampel bebas dan jika tidak memenuhi syarat dilanjutkan dengan uji Mann Whitney $U$ dengan menggunakan alfa $95 \%$.

\section{HASIL}

\section{Mutu Organoletik Cookies}

disukai oleh 63\%. Demikian juga dari aspek aroma, Cookies F1 disukai oleh $86 \%$ panelis dan Cookies F2 disukai oleh 54\% panelis. 


\section{Skor Mutu Organoleptik Cookies}

Tabel 2.

Skor Mutu Organoleptik Cookies Penambahan Tepung Bekatul dan Ikan Kembung

\begin{tabular}{lccc}
\hline Aspek organoleptik & Cookies F1 & Cookies F2 & Nilai $\mathrm{p}^{*}$ \\
\hline Warna & 3,97 & 3,77 & 0,511 \\
Tekstus & 3,85 & 3,80 & 0,787 \\
Aroma & 4,48 & 3,71 & 0,003 \\
Rasa & 4,48 & 3,38 & 0,013 \\
\hline
\end{tabular}

*Uji Mann Whitney $U$

Berdasarkan hasil uji statistic menunjukkan bahwa dari tidak ada perbedaan mutu organoleptik antara Cookies F1 dengan Cookies F2 dari aspek aspek warna $(\mathrm{p}=0,511)$ dan aspek tekstur $(\mathrm{p}=0787)$. Artinya, Cookies penambahan tepung bekatul dan tepung ikan kembung dapat disukai oleh panelis seperti panelis menyukai warna dan tekstur Cookies asli. Namun dari aspek aroma dan rasa, hasil analisis statistic menunjukkan bahwa organoletik Cookies asli lebih tinggi secara signifikan dibandingkan Cookies tepung bekatul dan ikan kembung, yaitu aroma $(\mathrm{p}=0,003)$ dan rasa $(\mathrm{p}=0,013)$.

\section{PEMBAHASAN}

Warna merupakan salah satu faktor yang sangat penting dalam penerimaan atau penolakan suatu produk karena kesan pertama yang dilihat panelis (Fitri, 2017). Warna merupakan hal yang pertama kali mempengaruhi seseorang untuk menentukan suka atau tidak suka terhadap produk tersebut. Warna Cookies tepung bekatul dan ikan kembung pada penelitian ini tidak berbeda dengan dengan cookies asli. Hal ini sejalan dengan penelitian yang dilakukan oleh Nadimin (2018), tentang Daya terima terhadap jajanan lokal Sulawesi Selatan subtitusi tepung ikan gabus (Channa Striata). Hal ini juga sejalan dengan penelitian Rahmawati (2013) Pengaruh Subtitusi Tepung Tempe dan Subtitusi Tepung Ikan Teri Nasi Terhadap Kandungan Protein, Kalsium dan
Organoleptik Cookies yang menyatakan bahwa subtitusi tepung tempe dan tepung ikan teri nasi berpengaruh nyata terhadap rasa, aroma, dan tekstur, tetapi tidak berpengaruh nyata terhadap warna cookies. Penelitian yang juga dilakukan Aini (2014) tentang Formulasi Biskuit Blondo Dan Tepung Ikan Gabus.

Tekstur merupakan atribut penilaian yang mempengaruhi penerimaan panelis terhadap daya terima. Tekstur bersifat kompleks dan dengan struktur bahan yang terdiri dari tiga elemen yaitu: mekanik (kekerasan, kekenyalan), geometric (berpasir, beremah), dan mouthfeel (berminyak, berair). (Setyaningsih, 2010). Hasil penelitian cookies dengan subtitutusi tepung bekatul dan tepung ikan kembung terhadap aspek tekstur yang paling disukai adalah cookies asli. Hal ini disebabkan karena cookies asli lebih banyak komposisi terigu dimana terigu mengandung gluten. Gluten adalah suatu senyawa yang bersifat kenyal dan elastis, yang berperan dalam menentukan kualitas makanan seperti tekstur. Tepung ikan dan tepung bekatul tidak mempunyai gluten. Sehingga jika penambahan tepung bekatul dan tepung ikan kembung yang terlalu tinggi dapat mempengaruhi tekstur cookies tersebut. Hasil penelitian serupa sebelumnya juga melaporkan hasil yang sama dimana penambahan tepung bekatul maupun tepung ikan sampai pada kosentrasi tertentu tidak menurunkan kesukaan panelis pada produk tersebut (Astiti, 2010; 
Purnamasari, 2017; Tahir, 2017). Berbeda dengan penelitian yang dilakukan oleh Saputra, (2018) menunjukkan bahwa terdapat perbedaan yang nyata antara cookies standar dengan cookies formula lainnya. Hal ini juga sama dengan penelitian yang dilakukan oleh Hana $\mathrm{T}$ (2017) yang melaporkan bahwa semakin tinggi subtitusi tepung ikan gabus pada bagea maka semakin rendah daya terima panelis terhadap tekstur bagea ikan gabus. Tepung ikan gabus tidak mengandung gluten yang merupakan komponen penting dalam mempengaruhi tekstur bagea.

Aroma adalah bau yang ditimbulkan oleh rangsangan kimia yang tercium oleh syarf-syaraf olfakori yang berada dalam rongga hidung ketika makanan masuk kedalam mulut (Winarno, 2004). Hasil penelitian ini menujukkan cookies dengan subtitutusi tepung bekatul dan tepung ikan kembung terhadap aspek aroma kurang disukai disbanding cookies asli. Penambahan tepung ikan kembung cenderung menghasilkan aroma amis pada cookies. Aroma dari suatu produk terdeteksi ketika zat yang mudah menguap (volatil) dari produk tersebut terhirup dan diterima oleh sistem penciuman sehingga panelis lebih memilih cookies standar/asli dibandingkan cookies penambahan tepung bekatul dan ikan kembul. Penelitian ini juga sejalan dengan penilitian yang dilakukan Nadimin (2017) menunjukkan ada pengaruh penambahan tepung ikan gabus terhadap daya terima konsumen pada bangke sagu pada aspek aroma. Penggunaan tepung ikan gabus dalam jumlah banyak (lebih 5\%) cenderung menurunkan daya terima konsumen. Konsentrasi TIG yang terlalu tinggi cenderung menurunkan kesukaan terhadap jajanan lokal termasuk Bangke saju. Berbeda dengan penelitian yang dilakukan Purnamasari (2017), bahwa tepung ikan gabus sampai $15 \%$ tidak berpengaruh terhadap aroma bangke sagu.
Rasa merupakan aspek penting dalam menilai suatu makanan tertentu dengan menggunakan panca indera pengecap dan merupakan hal kedua setelah penampilan makanan dalam membentuk pilihan terhadap makanan dan orang-orang menilai cita rasa sebagai alasan utama untuk memilih makanan tertentu, setiap orang memiliki kepekaan berbeda-beda dalam menilai suatu produk/makanan (Fellows,2014). Hasil penelitian cookies dengan subtitutusi tepung bekatul dan tepung ikan kembung lebih disukai dibandingkan cookies tepung bekatul dan ikan kembung dar aspek rasa. Hal ini disebabkan karena rasa tepung bekatul dan tepung ikan kembung meiliki rasa yang khas. Bekatul dengan rasa yang terkadang pahit karena kandungan saponin bekatul, rasa khas bekatul muncul disebabkan oleh kandungan minyaknya (tokol, tokoferol, tokotrienol) rasa khas ikan yang cenderung amis yang berbeda dengan cookies pada umumnya memiliki rasa yang sudah biasa dikalangan masyarakat yaitu rasa manis sehingga jika ditambahkan tepung bekatul dan tepung ikan kembung membuat biskuit memiliki rasa khas ikan dan mempengaruhi daya terima biskuit. Hal ini menunjukkan bahwa subtitusi ikan kembung dan bekatul pada cookies memberikan pengaruh terhadap rasa cookies. Hal ini sejalan dengan penelitian (Wulandari, M, 2010) yang melaporkan ada perbedaan rasa antara biskuit dengan penambahan bekatul 0\% dengan biskuit bekatul 5\%, 10\%, 15\% dan 20\%. Biskuit bekatul $0 \%$ memiliki rasa yang hampir sama dengan biskuit bekatul 5\%, Sedangkan untuk biskuit dengan penambahan bekatul 10\%, $15 \%$ dan $20 \%$ mempunyai rasa agak manis dan rasa khas dari bekatul masih terasa. Semakin besar penambahan bekatul, rasa manisnya semakin berkurang karena rasa pahit bekatul mulai terasa. Sejalan dengan penilitan yang dilakukan Charles (2019) Daya Terima Dan Anilisis Protein Dan 
Kalsium Pada Cheese Stick Dengan Subtitusi Tepung Ikan Kembung dimana terdapat perbedaan secara nyata antara cheese stick konsentrasi $0 \%, 5 \%$ dan $10 \%$. Sejalan dengan penelitian Nuraini (2017) tentang daya terima terhadap rasa yang paling disukai adalah biskuit ikan kembung dengan subtitusi $0 \%$ disusul subtitusi 5\% dengan nilai rata-rata 5.43. Sedangkan daya terima terhadap rasa yang paling tidak disukai adalah biskuit ikan kembung dengan subtitusi $15 \%$ dengan nilai rata 3.70. Penlitian yang dilakukan Nadimin (2017) The Effect of Local Snacks Enriched with Shell Flour on The Nutritional Status of Stunting Children menyatakan bahwa konsentrasi tepung kerang untuk camilan lokal tidak boleh melebihi $10 \%$ untuk menjaga daya yang diterima balita.

\section{KESIMPULAN}

Penambahan tepung bekatul dan tepung ikan kembung tidak mempengaruhi mutu organoleptik dari aspek warna dan tekstur cookies tepung bekatul dan ikan kembung. Aroma dan rasa cookies asli lebih disukai dibandingkan cookies penambahan tepung bekatul dan ikan kembung.

\section{DAFTAR PUSTAKA}

Aini 2014. Formulasi Biskuit Blondo dan Tepung Ikan Gabus (channa striata) yang Berpotensi Mengatasi Gizi Buruk Balita. Skripsi. Fakultas Ekologi Manusia Intitut Pertanian Bogor.

Astiti, Dewi. 2010. Kadar Pati Resisten, Kalsium, Dan Zat Besi Serta Daya Terima Kue Kering Tepung Pisang Kepok Dengan Penambahan Tepung Teri Kering Tawar. Artikel Penelitian. Universitas Diponerogo.

Charles. 2019. Daya Terima Dan Anilisis Protein Dan Kalsium Pada
Cheese Stick Dengan Subtitusi Tepung Ikan Kembung. Skripsi. Jurusan Gizi Politeknik Kesehatan Makassar.

Dinas Kesehatan Provinsi Sulawesi Selatan. 2017. Laporan Pemantau Status Gizi Provinsi Sulawesi Selatan Tahun 2017. Makassar; Seksi Gizi dan Kesehatan Keluarga Dinas Kesehatan Provinsi Sulawesi Selatan.

Dodik, Luthfianto., Retno Dwi N \& Indah Kurniati. 2017. Karakteristik Kandungan Gizi Bekatul Pada Berbagai Varietas Beras Di Surakarta. The $6^{\text {th }}$ University Research Colloquium. Malang; Universitas Muhammadiyah Magelang.

Fellows, P.J. 2014. Teknologi Pengelolahan Pangan Prinsip dan Praktik. Jakarta: Penerbit Buku Kedokteran EGC.

Fitri, Nuraini dan Eni Purwani. 2017. Pengaruh Subtitusi Tepung Ikan Kembung (Rastrelliger Brachysoma) Terhadap Kadar Protein Dan Daya Terima Biskuit. Prosiding Seminar. Universitas Muhammadiyah Surakarta

Hana T. 2017. Daya Terima dan Peningkatan Nilai Gizi Kalsium Jajanan Lokal (Bagea) yang Diperkaya Tepung Ikan Gabus Untuk Balita Stunting. Skripsi. Jurusan Gizi Politeknik Kesehatan Makassar.

Kemenkes RI. 2018. Laporan Riset Kesehatan Dasar (Riskesdas) Tahun 2018. Jakarta: Pusat Penelitian dan Pengembangan Kesehatan, Kementrian Kesehatan RI.

Kurnia, Pramudya., \& Purwani Eni. 2008. Pemanfaatan Ikan Kembung Sebagai Bahan Baku Tepung 
Ikan Ditinjau dari kadar Abu, Air, Protein, Lemak dan Kalsium. Jurnal Kesehatan. Volume 1 (1) : 30-46.

Nadimin. 2017. Pengaruh Subtitusi Tepung Ikan Gabus Terhadap Daya Terima Bangke Sagu. Media Gizi Pangan, Volume XXIV. Edisi 2 : 16-20

Nadimin, Nurjaya Dan Retno Sri Lestari. 2018. Daya Terima Terhadap Jajanan Lokal Sulawesi Selatan Subtitusi Tepung Ikan Gabus (Channa Striata). Aceh Nutrition Journal Volume 3 (2) :141-148.

Nadimin, Nurjaya Dan Siti Saharia Rowa. 2017. The Effect of Local Snacks Enriched with Shell Flour on The Nutritional Status of Stunting Children. Dama International Journal of Researchers (DIJR) Vol 2 (7) : 57-62.

Nalendrya, Iwenda., Ibnu Malkan \& Firlia Ayu A. 2016. Sosis Ikan Kembung (Rastrelliger Kanagurta L.) Sebagai Pangan Sumber Omega 3. Jurnal Aplikasi Teknologi Pangan. Volume 5 (3) :71-75.

Nuraini F dan Eni P. 2017. Pengaruh Subtitusi Tepung Ikan Kembung (Rastrelliger brachusoma) Terhadap Kadar Protein dan Daya Terima Biskuit.Surakarta : Universitas Muhamadiyah Surakarta.

Purnamasari. M. 2017. Pengembangan Jajanan Lokal (Kue Bangke Sagu) yang Diperkaya dengan Tepung Ikan Gabus untuk Makanan Tambahan Ibu Hamil KEK. Skripsi. Jurusan Gizi Politeknik Kesehatan Makassar.

Pravita Widaksi, Cory., Limin Santoso \& Siti Hudaidah. 2014. Pengaruh Subtitusi Ikan Dengan Tepung
Daging dan Tulang Terhadap Pertumbuhan Patin (Pangasius $s p)$. Jurnal Rekayasa dan Teknologi Budidaya Perairan. Volume 3 (1) : 304-311.

Rahmawati, Hestin dan Ninik Rustanti. 2013. Pengaruh Substitusi Tepung Tempe Dan Ikan Teri Nasi (Stolephorus Sp.) Terhadap Kandungan Protein, Kalsium, Dan Organoleptik Cookies. Journal of Nutrition College, Volume 2 (3) : 382-390.

Setyaningsih D. 2010. Analisi sensori untuk industri pangan dan Agro. Bogor : Institut Pertanian Bogor

Tahir S.H (2017). Peningkatan Nilai Protein dan Daya Terima Jajanan Lokal Baruasa dengan Penambahan Tepung Ikan Gabus.

Wulandari, Mita., \& Erma H. 2010. Pengaruh Penambahan Bekatul Terhadap Kadar Protein dan Sifat Organoleptik Biskuit. Jurnal Pangan dan Gizi. Volume 1 (2): 55-62.

Winarno, F.G. 2004. Kimia Pangan dan Gizi. Gramedia : Jakarta 